\title{
Jenis Dan Pemanfaatan Paku Pakuan Oleh Masyarakat Desa Ulak Jaya Kecamatan Sintang Kabupaten Sintang
}

\author{
Muhammad Syukur \\ Fakultas Pertanian Universitas Kapuas Sintang \\ Email : msyukur1973@yahoo.co.id
}

\begin{abstract}
Abstrak : Penelitian ini bertujuan untuk mengetahui jenis dan pemanfaatan paku pakuan oleh masyarakat desa Ulak Jaya Kecamatan Sintang Kabupaten Sintang.

Penelitian ini dilaksanakan dengan menggunakan jalur/transek dan wawancara. Pembuatan jalur dilakukan untuk mengamati jenis paku-pakuan sedangkan wawancara dilakukan untuk mengetahui pemanfaatan paku-pakuan oleh masyarakat setempat. Penetapan jalur dilakukan dengan metode "Purposive Sampling" yaitu menetapkan jalur pengamatan secara sengaja. Metode ini dipilih dengan pertimbangan lokasi penelitian dan keterwakilan seluruh kawasan. Jalur pengamatan di buat sebanyak 2 (dua) buah, pada setiap jalur dilakukan eksplorasi, inventarisasi dan identifikasi jenis paku-pakuan.

Hasil penelitian pada lokasi penelitian ditemukan 7 (tujuh) jenis Paku-Pakuan yaitu Marsilea crenata, Dicranopteris linearis, Nephrolepis sp, Nephrolepis exaltera, Circinate vernation, Nephrodopsis sp dan Nephrodopsis hirsula. Diantara 7 jenis paku-pakuan yang ditemukan, terdapat 3 jenis yang dapat dikonsumsi sebagai sayur, 1 jenis untuk bahan baku kerajinan tangan, 1 jenis untuk tumbuhan hias dan 2 jenis berfungsi sebagai obat (obat alergi dan infeksi luka) serta sebagai penambah ASI.
\end{abstract}

Kata Kunci : Jenis Paku-Pakuan, Pemanfaatan dan Masayarakat desa Ulak Jaya

\section{PENDAHULUAN}

Salah satu keanekaragaman hayati yang terdapat pada suatu kawasan baik hutan maupun areal bukan hutan adalah tumbuhan dari golongan Paku-Pakuan. Tumbuhan Paku-Pakuan, diketahui mempunyai peranan penting bagi ekosistem hutan dan manusia. Peranan tumbuhan Paku-Pakuan bagi ekosistem hutan adalah dalam proses pembentukan bunga tanah (humus) dan melindungi tanah dari erosi, sedangkan manfaatnya bagi manusia tumbuhan ini mempunyai potensi sebagai sumber pangan, bahan dasar untuk kerajinan tangan, tanaman hias, obat-obatan bahkan sebagai media tanam dalam budidaya tanaman. 
Jenis Dan Pemanfaatan Paku Pakuan Oleh Masyarakat Desa Ulak Jaya Kecamatan Sintang Kabupaten Sintang

Tumbuhan paku-pakuan (Pteridophyta) merupakan salah satu kelompok tumbuh-tumbuhan yang mempunyai banyak jenis. Diperkirakan jenis paku-pakuan di dunia ada 10.000 jenis dan Indonesia memiliki 1.300 jenis tumbuhan pakupakuan (Pteridophyta) dan masingmasing tumbuhan paku-pakuan mempunyai ciri tersendiri.

Kawasan Desa Ulak Jaya Kecamatan Sintang kabupaten Sintang mempunyai keanekaragaman jenis Paku-Pakuan yang cukup tinggi, namun sampai saat ini belum terdata dengan baik. Informasi mengenai jenis tumbuhan paku pakuan ini perlu mendapatkan perhatian, terutama dalam rangka upaya pelestarian dan perlindungan guna mempertahankan peranannya dalam ekosistem dan pemanfaatan pemenuhan kebutuhan oleh manusia.

\section{METODE PENELITIAN}

Penelitian ini dilaksanakan dengan menggunakan jalur/transek dan wawancara. Pembuatan jalur dilakukan untuk mengamati jenis paku-pakuan sedangkan wawancara dilakukan untuk mengetahui pemanfaatan paku-pakuan oleh masyarakat setempat. Penetapan jalur dilakukan dengan metode "Purposive Sampling" yaitu menetapkan jalur pengamatan secara sengaja. Metode ini dipilih dengan pertimbangan lokasi penelitian dan keterwakilan seluruh kawasan. Jalur pengamatan di buat sebanyak 2 (dua) buah, pada setiap jalur dilakukan eksplorasi, inventarisasi dan identifikasi jenis paku-pakuan

Jenis-jenis Paku-Pakuan yang ditemukan diidentifikasikan dan diinventarisasi untuk dideskripsikan ciri-ciri morfologisnya. Setiap jenis Paku-Pakuan yang ditemukan dikoleksi (dibuatkan herbarium). Wawancara dengan masyarakat dilakukan untuk mendapatkan informasi mengenai nama lokal Paku-pakuan dalam bahasa setempat dan pemanfaatannya..

\section{HASIL DAN PEMBAHASAN}

Berdasarkan hasil penelitian ditemukan sebanyak 7 (tujuh) jenis Paku-pakuan yang terdapat di desa Ulak Jaya Kecamatan Sintang Kabupaten Sintang. Daftar jenis Paku-Pakuan dapat dilihat pada tabel berikut ini. 
Jenis Dan Pemanfaatan Paku Pakuan Oleh Masyarakat Desa Ulak Jaya Kecamatan Sintang Kabupaten Sintang

Tabel . Jenis Paku-Pakuan Hasil Penelitian

No.

Nama Lokal

Nama Ilmiah

1. Paku Rajang

Marsilea crenata

2. Paku Resam

Dicranopteris linearis

3. Paku Pantai

Nephrolepis sp

4. Paku Bekeruk

Nephrolepis exaltera

5. Paku Kelinang

Circinate vernation

6. Paku Gunung

Nephrodopsis $s p$

7 Paku Hutan

Nephrodopsis hirsula

1. Paku Rajang

Paku Rajang adalah jenis Paku-

Pakuan yang tumbuh menempel pada batang kayu. Paku jenis ini hanya

dimanfaatkan/digunakan untuk tanaman hias oleh masyarakat setempat dan belum diketahui manfaat lainnya. Paku Rajang dapat dilihat pada gambar di bawah ini.

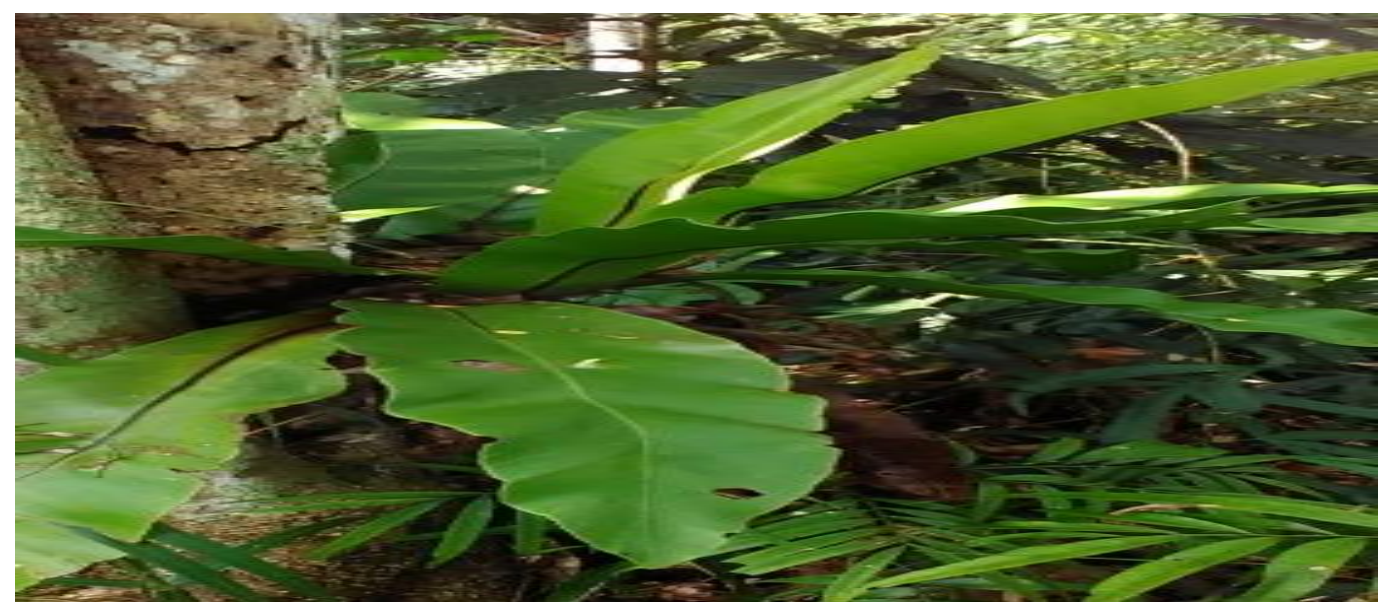

Gambar Paku Rajang (Marsilea crenata) 
Jenis Dan Pemanfaatan Paku Pakuan Oleh Masyarakat Desa Ulak Jaya Kecamatan Sintang Kabupaten Sintang

2. Paku Resam

Paku Resam dikenal sebagai tumbuhan invasif di beberapa tempat karena mendominasi permukaan tanah menyebabkan tumbuhan lain terhambat pertumbuhannya. Paku Resam dapat digunakan untuk bahan baku kerajinan tangan, terutama akar dan batangnya. Batang Paku Resam dapat dibuatkan untuk menangkap ikan (Bubu) dan akarnya digunakan untuk mengikat pada proses pembuatan alat rumah tangga seperti Takin (Keranjang) maupun dijadikan sebagai media tanam (pakis Blok). isik Paku Resam dapat dilihat pada gambar berikut ini.

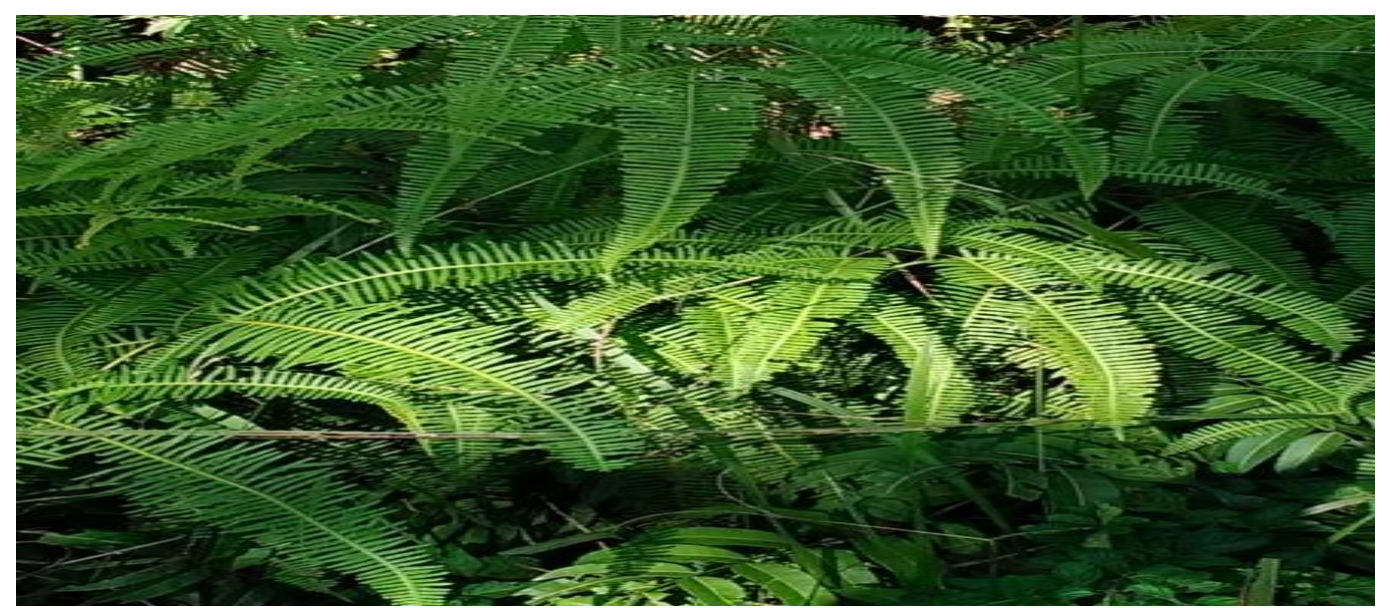

Gambar Paku Resam ((Dicranopteris linearis)

\section{Paku Pantai}

Paku Pantai termasuk jenis yang paling dikenal oleh masyarakat setempat, karena jenis ini banyak dikonsumsi sebagai sayur. Paku Pantai tumbuh di lantai hutan, terutama pada area yang relatif terbuka dan terlihat lebih subur dibandingkan dengan sekitarnya. Paku Pantai biasanya digunakan untuk membuat cah atau tumis sayur pakis, campuran pada sup dan sebagai lalapan. Gambar Paku Pantai dapat dilihat pada gambar berikut ini 
Jenis Dan Pemanfaatan Paku Pakuan Oleh Masyarakat Desa Ulak Jaya Kecamatan Sintang Kabupaten Sintang

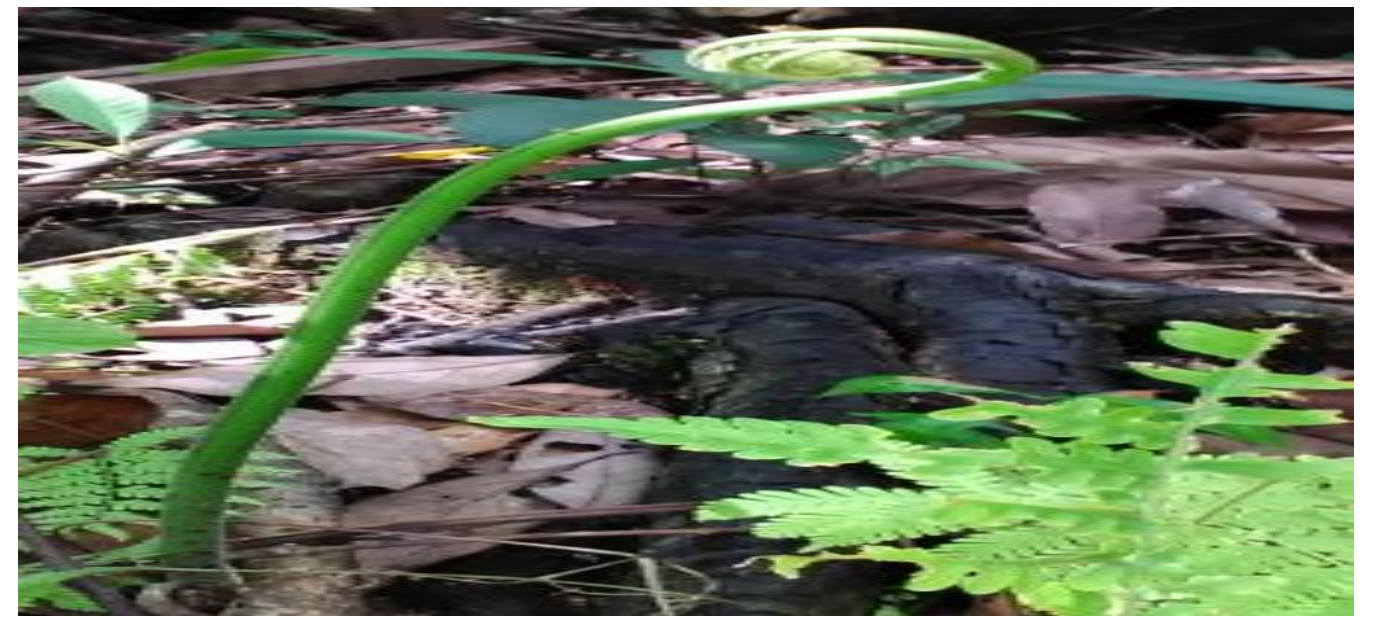

Gambar Paku Pantai (Nephrolepis sp)

4. Paku Bekeruk

Paku Bekeruk merupakan paku tanah (tumbuh di tanah). Akar rimpang tegak, berdaun lebat, tangkai daun 10-60 $\mathrm{cm}$, pangkalnya gundul atau bersisik jarang. Anak daun duduk atau hampir duduk, kerapkali dengan sisik yang berkapur, yang terbawah agak berjauhan, ujung menyempit, lancip.
Anak daun fertil lurus atau berbentuk sabit pada pangkal, tepinya beringgit bergerigi ringan, urat daun sejajar berdekatan rapat, diakhiri pada sorus atau pori air. Paku Bekeruk digunakan sebagai sayur, yang bermanfaat untuk menambah ASI bagi ibu menyusui. Paku Bekeruk dapat dilihat pada gambar berikut ini

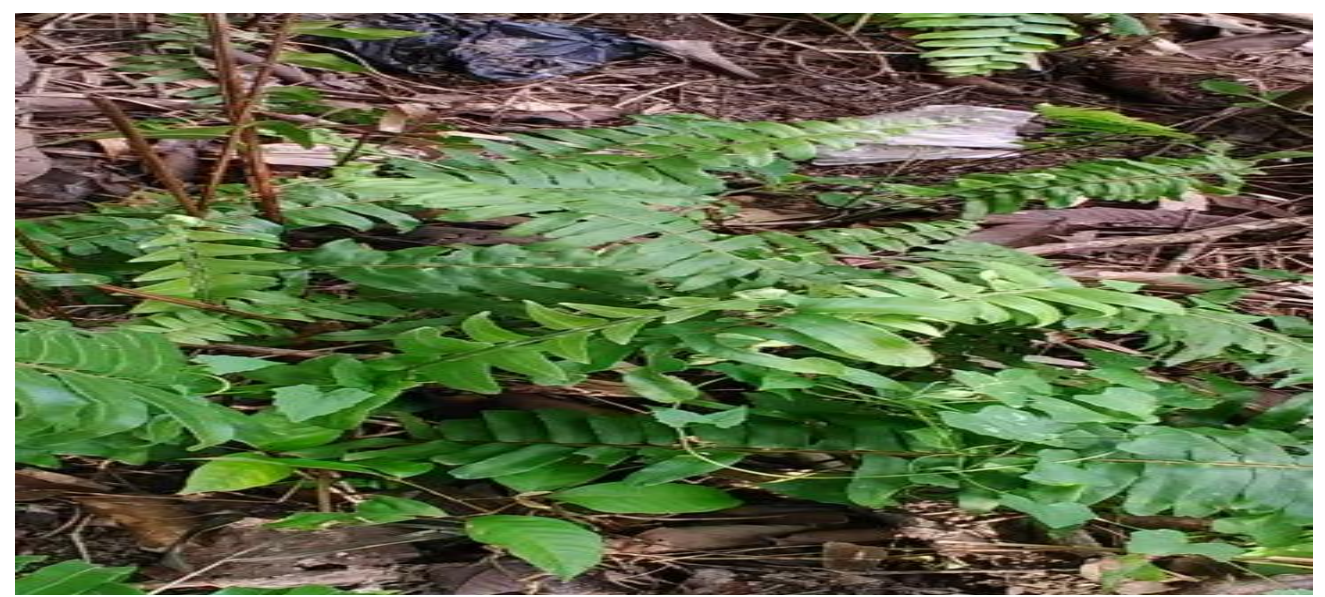

Gambar Paku Bekeruk Nephrolepis exaltera 
Jenis Dan Pemanfaatan Paku Pakuan Oleh Masyarakat Desa Ulak Jaya Kecamatan Sintang Kabupaten Sintang

5. Paku Kelinang

Paku Kelinang biasanya

ditemukan pada berbagai kondisi

tempat tumbuh, seperti lantai hutan

yang lembab, tebing perbukitan, pohon atau bebatuan. Paku

Engkelinang digunakan masyarakat

setempat sebagai sayur. Morfologis

Paku Kelinanang dapat dilihat pada gambar berikut ini.

menempel atau merayap pada batang

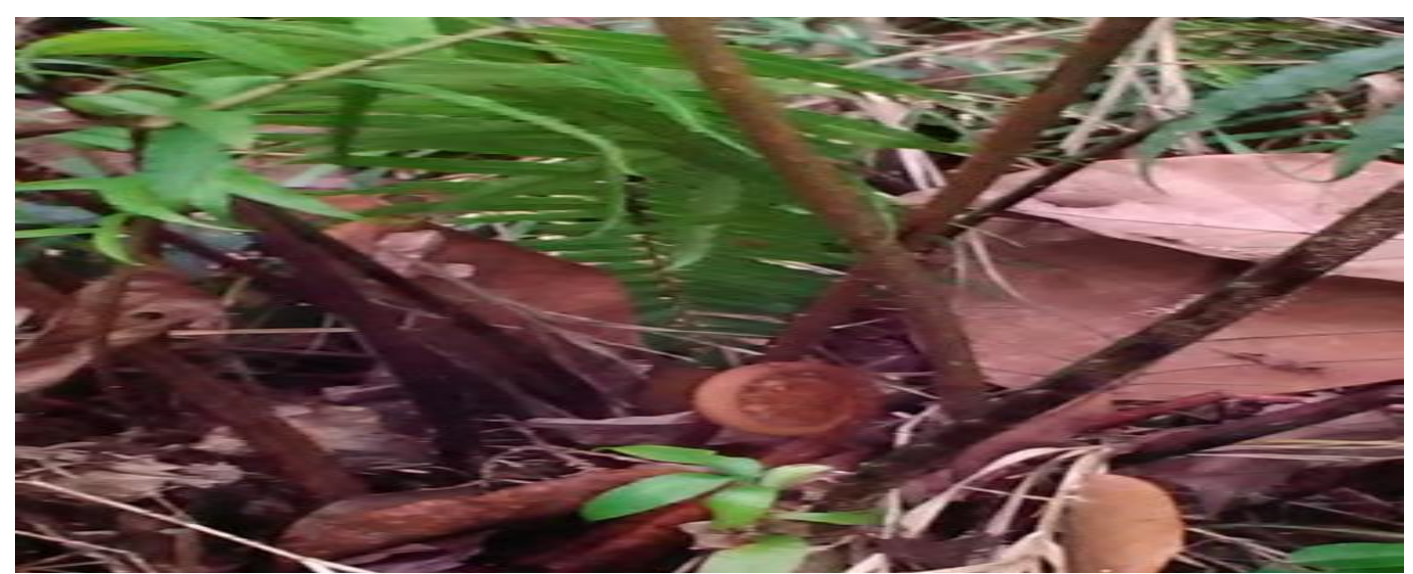

Gambar Paku Kelinang (Circinate vernation)

\section{Paku Gunung}

Paku Gunung ditemukan menempel pada pangkal batang pohon. Paku ini tidak dapat dikonsumsi sebagai sayur, tetapi bagi masyarakat setempat digunakan sebagai obat untuk alergi. Bagian yang digunakan adalah daun, yaitu dengan cara menggosokkan daun pada bagian yang alergi. Morfologis Paku Gunung dapat dilihat pada gambar. 
Jenis Dan Pemanfaatan Paku Pakuan Oleh Masyarakat Desa Ulak Jaya Kecamatan Sintang Kabupaten Sintang

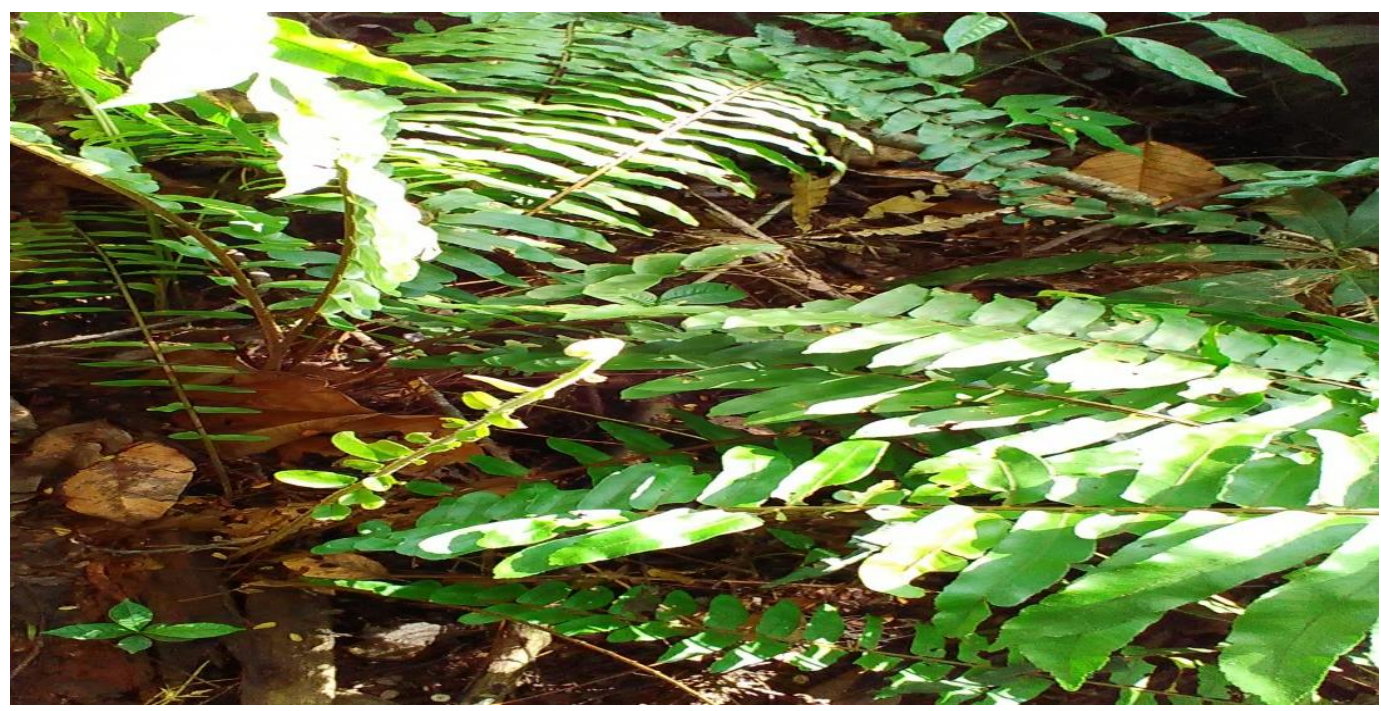

Gambar Paku Gunung (Nephrodopsis sp)

7. Paku Hutan

Paku Hutan ditemukan tumbuh langsung di tanah, termasuk jenis yang besar dibandingkan dengan paku lainnya. Paku ini digunakan oleh masyarakat sebagai obat, yaitu tertusuk benda tajam. Bagian yang digunakan adalah getahnya, yaitu dengan cara getah tangkai daun dioleskan pada bagian yang luka (infeksi). Morfologis Paku Hutan dapat dilihat pada gambar berikut ini. untuk mengatasi infeksi akibat

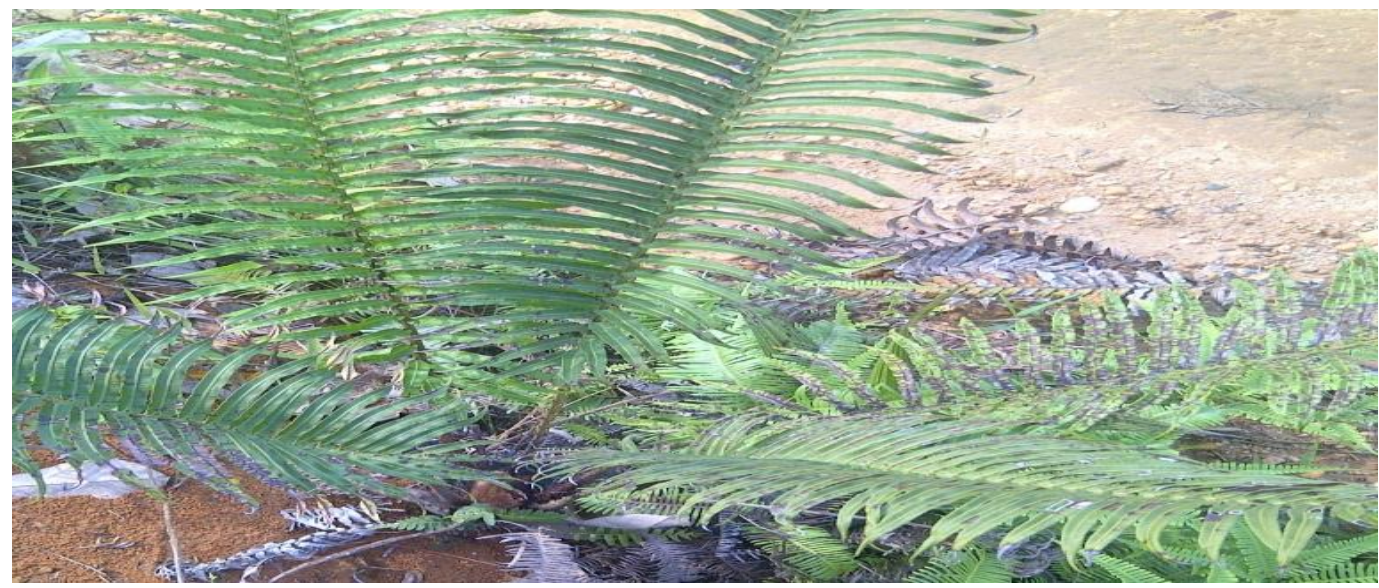

Gambar Paku Hutan (Nephrodopsis hirsula). 
Jenis Dan Pemanfaatan Paku Pakuan Oleh Masyarakat Desa Ulak Jaya Kecamatan Sintang Kabupaten Sintang

Berdasarkan hasil penelitian diketahui bahwa ditemukan 7 (tujuh) jenis paku-pakuan yaitu Paku Engkerajang, Paku Resam, Paku Pantai, Paku Bekeruk, Paku Engkelinang, Paku Gunung dan Paku Hutan. Berdasarkan manfaat dan kegunaannya, maka diketahui bahwa terdapat paku-pakuan yang dijadikan sebagai tanaman hias (Paku Engkerajang), paku untuk sayur (Paku Pantai, Paku Bekeruk dan Paku Engkelinang), paku untuk menambah ASI (Paku Bekeruk), paku untuk bahan baku kerajinan tangan (Paku Resam) dan Paku yang dapat digunakan untuk obat alergi dan infeksi bagian yang luka (Paku Gunung dan Paku Pantai).

Secara umum jenis PakuPakuan yang terdapat pada lokasi penelitian adalah jenis yang biasa ditemukan oleh masyarakat di Kalimantan Barat, walaupun dengan nama daerah yang berbeda-beda. Jumlah jenis paku-pakuan yang ditemukan relatif sedikit. Hal ini dapat dipahami karena karakteristik lokasi penelitian yang spesifik dataran tinggi (gunung), sehingga kondisinya seragam. Walaupun paku-pakuan umumnya adalah jenis pioner, tetapi apabila kondisi lahan sebagai tempat tumbuhnya seragam, maka yang tumbuh diatasnya relatif lebih sedikit (berkurang keanekaragamannya).

Paku-Pakuan adalah jenis tumbuhan yang paling dikenal dan banyak digunakan oleh masyarakat untuk dikonsumsi sebagai sayur. Bagi masyarakat Kalimantan secara umum dan terutama masyarakat Kelam Permai, menggunakan tumbuhan Paku-Pakuan sebagai sayur sudah dilakukan secara turun temurun. Hal ini tidak terlepas dari kondisi alam sekitar tempat tinggal yang umumnya hutan dan tersedia banyak sekali Paku-Pakuan. Selain itu, apabila mengambil langsung di alam tidak memerlukan biaya dan lebih ekonomis. Selain hal tersebut, paku-pakuan yang terdapat pada lokasi penelitian sesungguhnya memiliki nilai komersil terutama yang dapat digunakan sebagai obat. Apabila jenis ini dimanfaatkan secara terus menerus oleh masyarakat dikhawatirkan akan mengalami kepunahan. 
Jenis Dan Pemanfaatan Paku Pakuan Oleh Masyarakat Desa Ulak Jaya Kecamatan Sintang Kabupaten Sintang

\section{PENUTUP}

\section{Kesimpulan}

Berdasarkan hasil penelitian

dan pengamatan, maka dapat

disimpulkan sebagai berikut;

1. Pada lokasi penelitian ditemukan

7 (tujuh) jenis Paku-Pakuan yaitu

Paku Rajang (Marsilea crenata),

Paku Resam (Dicranopteris

linearis), Paku Pantai

(Nephrolepis sp), Paku Bekeruk

(Nephrolepis exaltera), Paku

Kelinang (Circinate vernation),

Paku Gunung (Nephrodopsis sp)

dan Paku Hutan (Nephrodopsis

hirsula).

2. Diantara 7 jenis paku-pakuan yang ditemukan, terdapat 3 jenis yang dapat dikonsumsi sebagai sayur, 1 jenis untuk bahan baku kerajinan tangan, 1 jenis untuk tumbuhan hias dan 2 jenis berfungsi sebagai obat (obat alergi dan infeksi luka) serta sebagai penambah ASI.

\section{Saran}

Perlu kajian yang lebih mendalam untuk dapat memastikan kenaekaragaman jenis paku-pakuan melalui penelitian dengan waktu yang lebih lama dan perlu dilakukan upaya-upaya yang konkrit oleh pemerintah dan seluruh stakeholder untuk menjaga sekaligus menjamin kelestarian fungsi kawasan.

\section{DAFTAR PUSTAKA}

MacKinnon, J. dan Kathy MacKinnon. 1990. Pengelolaan Kawasan Yang Dilindungi Di Daerah Tropika. Gadjah Mada University Press. Yogyakarta.

Polunin, N. 1990. Pengantar Geografi Tumbuhan Dan Beberapa Ilmu Serumpun.

diterjemahkan Gembong Tjitrosoepomo. Gadjah Mada University Press. Yogyakarta.

Rismunandar, Ekowati, M. 1991. Tanaman Hias Pakupakuan. Penebar Swadaya. Jakarta.

Sastrapradja, S. dan J. J. Afriastini. 1985. Kerabat Paku. LBN - LIPI. Balai Pustaka. Jakarta.

Soeseno, S. 1991. Suplir, Perawatan dan Pembibitan Paku Hias. Gramedia Pustaka Utama. Jakarta. 
Jenis Dan Pemanfaatan Paku Pakuan Oleh Masyarakat Desa Ulak Jaya Kecamatan Sintang Kabupaten Sintang

Tjitrosoepomo, G. 1986. Taksonomi

Tumbuhan. Bharata

Karya Aksara. Jakarta.

Wandi, Hanna Artuti Ekamawanti dan Tri Widiastuti, 2016, Keanekaragaman Jenis
Vegetasi Penyusun

Tembawang Di Desa Bangun Sari Kecamatan Teriak Kabupaten Bengkayang, Jurnal Hutan Lestari Vol 4 (4), Universitas Tanjungpura

Pontianak. 